\title{
Splenic trauma - our experience at a level I Trauma Center
}

\author{
Dalak travması - I. Basamak Travma Merkezi’ndeki deneyimimiz
}

\author{
Gyan SAURABH, Subodh KUMAR, Amit GUPTA, Biplab MISHRA, Sushma SAGAR, \\ Maneesh SINGHAL, Rehan N KHAN, Mahesh C MISRA
}

\section{BACKGROUND}

A retrospective study was performed to identify the effect of non -operative management on splenic trauma patients and its implications at our Level I Trauma Centrer between January 2007 and June 2008.

\section{METHODS}

Data regarding patient demography, mode of splenic injury, computerized tomography (CT) grading, blood transfusion requirement, operative findings, hospital stay, and followup were collected. The results of abdominal sonography and CT scan were utilized as proof of splenic injury and to determine the grade of injury. Subjects were divided into splenectomy and non-operative groups. Results were analyzed using non-parametric Mann-Whitney U tests.

\section{RESULTS}

Sixty-seven patients were enrolled in this study. All patients with grade I injury and 12 of 13 patients with grade II injury were managed non-operatively, whereas 9 of 16 patients with grade III injuries, 12 of 14 patients with grade IV injuries and all patients with grade $\mathrm{V}$ injuries were managed operatively. Thus, the higher the grade of injury, the greater the likelihood of operative management. The mean Injury Severity Score of the operative group was 20.12, significantly higher $(p=0.001)$ than in the non-operative group, at 11.9. Mean hospital stays in the operative and non-operative groups were 12.8 and 8.3 days, respectively.

\section{CONCLUSION}

Non-operative management of splenic trauma can be performed with an acceptable outcome.

Key Words: Splenic trauma; splenectomy; non-operative management.

\section{AMAÇ}

Non-operatif tedavinin dalak travmalı hastalar üzerindeki etkilerini belirlemek üzere, I. Basamak Travma Merkezimizde Ocak 2007 ile Haziran 2008 tarihleri arasında retrospektif bir çalışma yürütüldü.

\section{GEREÇ VE YÖNTEM}

Hasta demografisi, dalak yaralanması biçimi, bilgisayarl1 tomografi (BT) evrelemesi, kan transfüzyon gereksinimi, cerrahi bulgular, hastanede kalış ve takip ile ilgili bilgiler toplandı. Splenik yaralanmanın kanıtı olarak ve yaralanmanın evresini belirlemek üzere, karın ultrasonografisi ve BT tarama sonuçları kullanıldı. Hastalar splenektomi ve non-operatif gruplarına ayrıldı. Bulgular non-parametrik Mann-Whitney U testiyle analiz edildi.

\section{BULGULAR}

Altmış yedi hasta çalışmaya alındı. Evre I yaralanması olan bütün hastalarla evre II yaralanması bulunan 13 hastanın 12'si non-operatif olarak tedavi edilirken, evre III 16 hastanın 9'u, evre IV 14 hastanın 12'si ve evre V bütün hastalar cerrahi yöntemle tedavi edildi. Bu nedenle, ne kadar yüksek yaralanma derecesi söz konusu ise o kadar çok operatif tedavi gerçekleşti. Operatif grubun ortalama Yaralanma Şiddet Skoru $(20,12)$, non-operatif grubun Yaralanma Şiddet Skorundan $(11,9)$ anlamlı şekilde daha yüksek bulundu $(\mathrm{p}=0,001)$. Operatif ve non-operatif gruplardaki ortalama hastane kalışları, sırasıyla 12,8 ve 8,3 gün idi.

\section{SONUÇ}

Dalak travmasının non-operatif tedavisi kabul edilebilir sonuçlarla uygulanabilmektedir.

Anahtar Sözcükler: Splenik travma; splenektomi; non-operatif tedavi. 
Until recently, the accepted treatment for splenic trauma, even for minor injuries, was splenectomy. This aggressive approach was based on the belief that, in adulthood, the spleen does not contribute to any major function, and non-operative management (NOM) was associated with potential life-threatening hemorrhage. With increasing recognition of the role of the spleen in immunological function and awareness of overwhelming post-splenectomy infection (OPSI), atherogenesis and ischemic diseases, there has been an increasing trend towards NOM and splenic salvage procedure. ${ }^{[1]}$ However, this policy change towards splenic conservation requires careful risk-benefit analysis in the face of potentially life-threatening hemorrhage from delayed splenic rupture and the possibility of transfusion-induced viral infections. Furthermore, the increasing availability of reliable and good quality radiological imaging, including ultrasound and computerized tomography (CT) scanning, has greatly improved the information available with regard to the nature of the splenic injury, and this may well help to identify the suitable patients for $\mathrm{NOM}^{[2]}$ but at the expense of radiation to the patient.

We have reviewed the outcome of splenic injuries from our tertiary trauma center with the main aim of examining the effect of this changed non-operative policy on patients and its implications.

\section{MATERIALS AND METHODS}

We have undertaken a retrospective study of patients with splenic injury admitted to our tertiary trauma center (located in New Delhi, India) between January 2007 and June 2008. Patients were identified with the help of clinical coding data on a Centralized Patient Record System (CPRS). Coding data were extracted from documentation found in the patient casenote and operation theater register. Data regarding patient demographics, mode of splenic injury, pre-op-

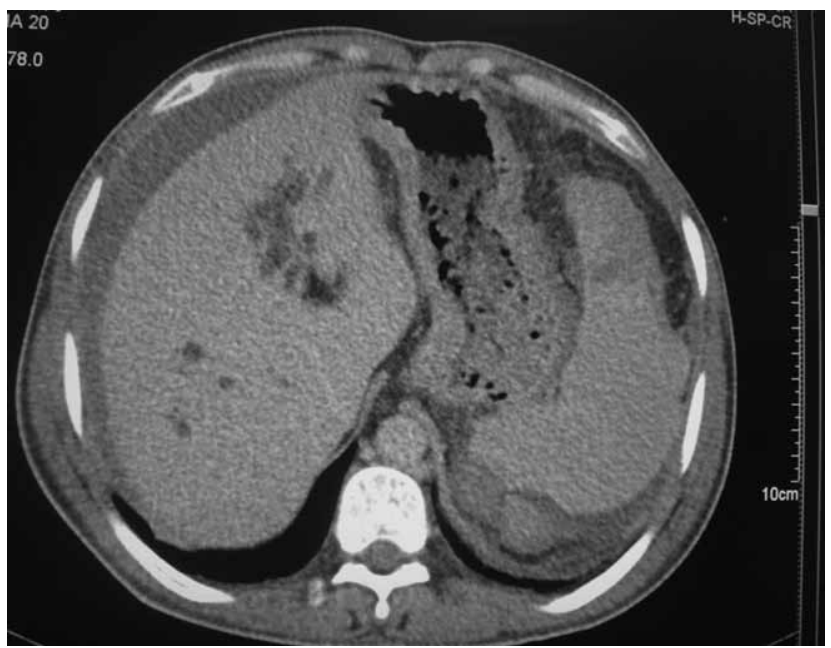

Fig. 1. Abdominal CT - Grade II splenic trauma. erative investigations, operative findings, and followup were collected. For each patient, an Injury Severity Score (ISS) ${ }^{[3]}$ was calculated. All CT scans performed on admission were blindly and retrospectively reviewed by an otherwise uninvolved senior radiologist to grade splenic injury from grade I to $\mathrm{V}$ according to the American Association for the Surgery of Trauma (AAST) Splenic Injury Grading Scale. Transfusion requirements, length of hospital stay and the use of imaging in follow-up were also recorded. Follow-up status reports of all patients were obtained from their concerned admitting surgical units. Patients were placed into one of two groups based on the planned intervention, as splenectomy group or non-operative group.

Statistical analysis of the data was performed using non-parametric Mann-Whitney U tests.

\section{RESULTS}

Sixty-seven patients were enrolled in this study, 5 of whom were children less than 15 years of age who were excluded from the study. The mean age was 25.25 years (16-60 years). These cases included isolated splenic injuries as well as polytrauma. As expected, males were predominantly affected, with a male:female ratio of 5.7:1. Sixty-four $(95.5 \%)$ patients had blunt abdominal trauma and $3(4.5 \%)$ had penetrating trauma. Among patients with blunt abdominal trauma, motor vehicle crash was the most common cause, in $38(61.3 \%)$, followed by fall from height in $19(30.6 \%)$ and assault in $5(8 \%)$.

Most of the patients who suffered blunt splenic trauma were young males less than 30 years of age $(70 \%)$. Of the 67 patients who underwent CT scan, 21 had grade I injury, 13 had grade II (Fig. 1), 16 had grade III, 14 had grade IV (Fig. 2), and 3 had grade V (Figs. 3 and 4). All patients with grade I injury and 12 of 13 patients with grade II injury were managed non-



Fig. 2. Abdominal CT - Grade IV splenic trauma. 
Table 1. Demographic and clinical characteristics of patients with splenic trauma

\begin{tabular}{lccc}
\hline & $\begin{array}{c}\text { Splenectomy } \\
(\mathrm{N}=25)\end{array}$ & $\begin{array}{c}\text { Non-operative } \\
(\mathrm{N}=42)\end{array}$ & $\mathrm{p}$ \\
\hline Mean age & 23 & 25 & $>0.05$ \\
Sex (Male : Female) & $5.6: 1$ & $5.8: 1$ & $>0.05$ \\
Injury Severity Score & 20.12 & 11.9 & $<0.001$ \\
Blood transfusion & 4.04 & 1.4 & $<0.001$ \\
Mean hospital stay & $7-26(12.8)$ & $7-22(9.9)$ & 0.005 \\
Mean ICU stay & $7-18(10.6)$ & $7-12(7.8)$ & $<0.05$ \\
Lowest hemoglobulin in first 24 hrs (g/L) & $9.3 \pm 1.37$ & $11.4(9.8-12.8)$ & 0.002 \\
Admission systolic blood pressure & $89(60-101)$ & $112(100-140)$ & 0.001 \\
Admission pulse rate & $112(81-128)$ & $93(81.5-109)$ & 0.10 \\
Positive initial USG & 23 & 35 & $>0.05$ \\
$\geq 3$ regions injured & $12(48 \%)$ & $7(16.6 \%)$ & 0.06 \\
\hline
\end{tabular}

operatively. Nine of 16 patients with grade III injuries, 12 of 14 patients with grade IV injuries and all patients with grade $\mathrm{V}$ injuries were managed operatively. That is, the higher the grade of injury, the greater the likelihood of operative management.

Of 25 patients who were managed operatively, 2 underwent splenorrhaphy (1 with grade II and 1 with grade III splenic injury). All 3 of the penetrating splenic trauma patients underwent splenectomy. A splenic artery embolization facility was not available in our center during the time this study was performed.

Transfusion requirement (Table 1) was 4.04 units in the operative group and 1.4 units in the non-operative group $(\mathrm{p} \leq 0.001)$. Mean hospital stay in the operative group was 12.8 days (range 7-26) and in the nonoperative group was 8.3 days (range $7-16)(p=0.005)$. Because systolic blood pressure (SBP) at presentation is a major determinant of the management of blunt splenic injuries (BSIs), the majority of patients in the operative group, 19 (76\%), had SBP $<90 \mathrm{mmHg}$ at presentation. One patient in the operative group was initially managed non-operatively but later required

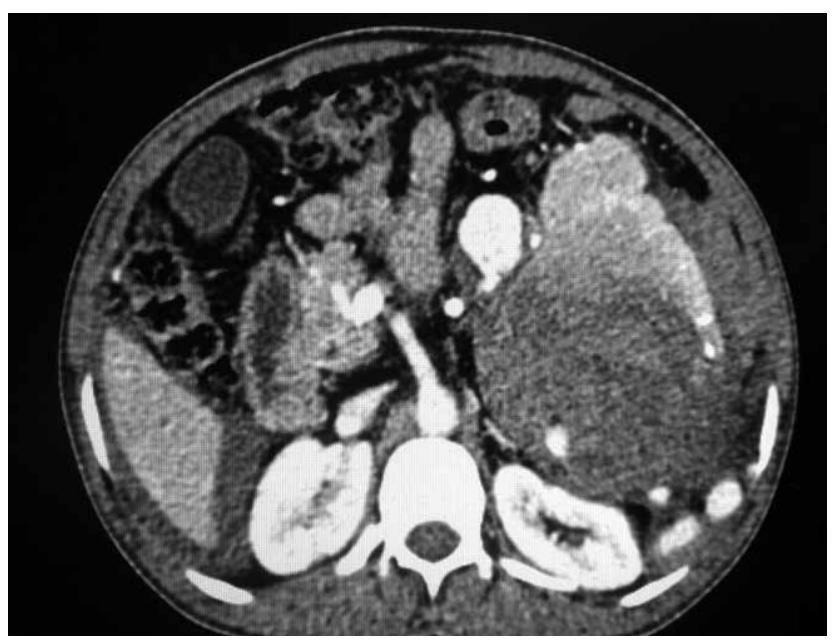

Fig. 3. Abdominal CT - Grade V splenic trauma. splenectomy due to the failure of NOM. Again, the cause of failed NOM was hypotension. Out of 42 patients in the non-operative group, 37 had normal SBP at presentation and 5 had shock due to related injuries, but they were later stabilized after resuscitation.

The mean ISS of the operative group was 20.12, significantly higher $(p \leq 0.001)$ than in the non-operative group, with a mean ISS of 11.9.

Twelve patients in the splenectomy group and 7 patients in the non-operative group had associated injuries. Bilateral hemothorax in 5 and left hemothorax in 14 patients was managed with intercostal tube drainage alone. Four of 5 patients with bilateral hemothorax had associated multiple rib fractures, which required no surgical intervention apart from intercostal tube drainage. Four patients had mild head injury and 2 had moderate head injury managed with non-operative approach alone. Seven patients had associated liver injury (grade I-III) managed non-operatively. Six patients had associated long bone fracture managed with external fixation in 3 left humerus fractures and with internal fixation in 3 left femur fractures.

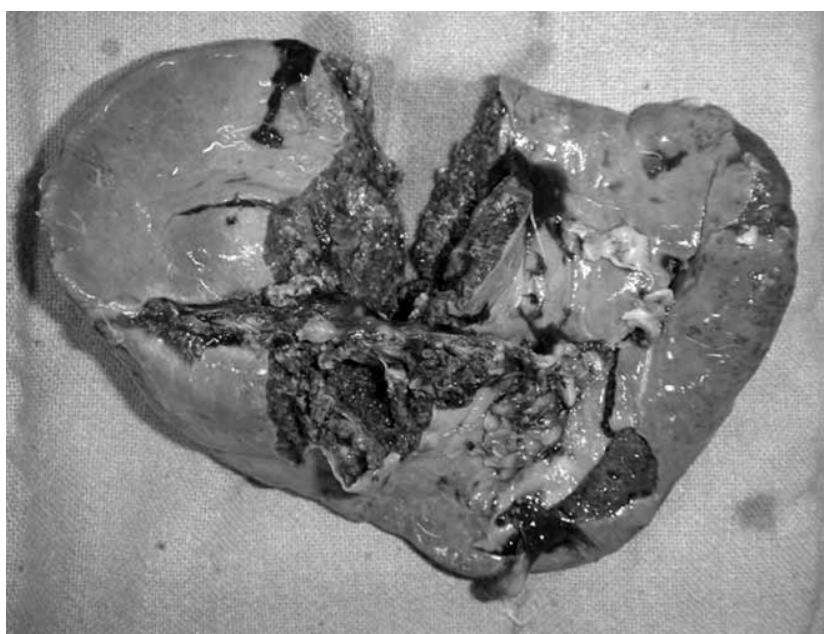

Fig. 4. Splenic injury involving the hilum. 
All the patients in the non-operative group with injury grades of III and IV were followed up weekly for six weeks, fortnightly for the next 12 weeks and then monthly thereafter until one year. At every visit, they were followed by clinical examination and ultrasonography. Patients with grade I and II splenic injuries were followed up fortnightly for two months and monthly for the next four months. Grade I and II splenic injury patients were followed up only clinically, but grade III and IV patients were followed up with monthly ultrasonography for three months followed by contrastenhanced CT scan at one year. At the one-year followup, all the patients are doing well with none presenting with features of delayed rupture or OPSI.

\section{DISCUSSION}

This study suggests that BSIs in adults could be successfully managed non-operatively in at least $63 \%$ of the patients; however, all the penetrating splenic injuries underwent splenectomy. The need for surgical intervention is usually decided within 24 hours of admission. Therefore, inpatient monitoring after BSI for 8 days should identify $>95 \%$ of failed NOM. Although success rates as high as $98 \%$ have been previously reported, ${ }^{[4]}$ success of NOM is undoubtedly a consequence of how often it is attempted. If one operates on most BSI patients and reserves NOM only for those with minor injuries, success rates would be anticipated. This is supported by recent results from a large multi-institutional study conducted by Peitzman and colleagues, ${ }^{[5]}$ who showed that when NOM was attempted, $61.5 \%$ of the time there was an associated $10.8 \%$ failure rate. The length of time that patients should be monitored as inpatients after BSI, at which point NOM should be considered successful and patients safe for discharge, is presently not well defined. The reported durations of observation after BSI have varied widely in the literature, with most studies reporting mean lengths of stay between 4.1 and 12 days. ${ }^{[6,7]}$ Mean hospital stay among our patients was 12.8 days in the splenectomy group and 8.3 days in the nonoperative group, which is longer than the international average, and may be attributed to the nature of the associated injuries.

Previous studies have suggested that splenic injury grade, ISS, Glasgow Coma Scale (GCS), initial BP, as well as other variables may be important predictors of failure of NOM for BSI. ${ }^{[8-11]}$ Our study suggests that splenic injury grade has a significant effect on the success of NOM, confirming the finding of Nix and colleagues. ${ }^{[11]}$ This was evident for both patients with isolated BSI and those with BSI and associated injuries. ISS is another factor, being significantly higher in patients with BSI requiring surgery and with higher rates of failed NOM seen with an increase in ISS. In our study, SBP on arrival was another effective fac- tor, and was significantly lower in the operative group than in the non-operative group. Taken together, our results suggest that higher grade injuries in more severely injured patients are more likely to cause failed NOM. The major complications that can be avoided by splenic conservation are thrombocytosis and OPSI. ${ }^{[12]}$ None of our patients developed OPSI in the followup. The obvious disadvantage of NOM is the possibility of sudden, severe, delayed hemorrhage leading even to death before surgical intervention can be arranged. ${ }^{[13]}$ In our series, only 1 of 42 patients deteriorated in the non-operative group and required urgent splenectomy. Other problems in NOM highlighted in the literature include the greater requirement of blood transfusions and transfusion-related complications. ${ }^{[2]}$ In our series, requirement of blood transfusions in the operative group was significantly higher than in the non-operative group. Another consideration for NOM is the possibility of missing other associated intra-abdominal injuries. None of our patients, to date, has presented with late associated injuries. It is stated that hospital stay for NOM patients is shorter than for patients undergoing operative management. ${ }^{[14,15]}$ Similarly, in our study, mean hospital stay for the NOM patients was shorter than for the operated group.

In conclusion, BSIs can be managed non-operatively in the majority of patients with an acceptable outcome even in the developing world well-equipped with the latest medical advancement and expertise. Selection of patients for operative versus non-operative treatment is difficult. Close in-patient monitoring for 8 days is essential to the successful non-operative management of the majority of patients.

\section{REFERENCES}

1. Mikocka-Walus A, Beevor HC, Gabbe B, Gruen RL, Winnett J, Cameron P. Management of spleen injuries: the current profile. Aust NZ J Surg 2010;80:157-61.

2. Aseervatham R, Muller M. Blunt trauma to the spleen. Aust NZ J Surg 2000;70:333-7.

3. Greenspan L, McLellan BA, Greig H. Abbreviated Injury Scale and Injury Severity Score: a scoring chart. J Trauma 1985;25:60-4.

4. Pachter HL, Guth AA, Hofstetter SR, Spencer FC. Changing patterns in the management of splenic trauma: the impact of nonoperative management. Ann Surg 1998;227:708-19.

5. Peitzman AB, Heil B, Rivera L, Federle MB, Harbrecht BG, Clancy KD, et al. Blunt splenic injury in adults: Multi-institutional Study of the Eastern Association for the Surgery of Trauma. J Trauma 2000;49:177-89.

6. Myers JG, Dent DL, Stewart RM, Gray GA, Smith DS, Rhodes JE, et al. Blunt splenic injuries: dedicated trauma surgeons can achieve a high rate of nonoperative success in patients of all ages. J Trauma 2000;48:801-6.

7. Harbrecht BG, Peitzman AB, Rivera L, Heil B, Croce M, Morris JA Jr, et al. Contribution of age and gender to outcome of blunt splenic injury in adults: multicenter study of the eastern association for the surgery of trauma. J Trauma 2001;51:887-95. 
8. Velmahos GC, Zacharias N, Emhoff TA, Feeney JM, Hurst JM, Crookes BA, et al. Management of the most severely injured spleen: a multicenter study of the Research Consortium of New England Centers for Trauma (ReCONECT). Arch Surg 2010;145:456-60.

9. Cathey KL, Brady WJ Jr, Butler K, Blow O, Cephas GA, Young JS. Blunt splenic trauma: characteristics of patients requiring urgent laparotomy. Am Surg 1998;64:450-4.

10. Stranes S, Klein P, Magagna L, Pomerantz R. Computed tomographic grading is useful in the selection of patients for non operative management of blunt injury to the spleen. Am Surg 1998;64:743-749.

11. Nix JA, Costanza M, Daley BJ, Powell MA, Enderson BL.
Outcome of the current management of splenic injuries. J Trauma 2001;50:835-42.

12. Finch R, Banting SW. Modern management of splenic injury. Aust NZ J Surg 2004; 74: 513-4. DOI: 10.1111/j.14452197.2004.03068.x

13. Benjamin CI, Engrav LH, Perry JF Jr. Delayed rupture or delayed diagnosis of rupture of the spleen. Surg Gynecol Obstet 1976;142:171-2.

14. Sanders MN, Civil I. Adult splenic injuries: treatment patterns and predictive indicators. Aust N Z J Surg 1999;69:430-2.

15. Smith JS Jr, Cooney RN, Mucha P Jr. Nonoperative management of the ruptured spleen: a revalidation of criteria. Surgery $1996 ; 120: 745-51$. 